POLSKA AKADEMIA UMIEJĘTNOŚCI

TOM XIII

KULTURA SŁOWIAN. ROCZNIK KOMISJI KULTURY SŁOWIAN PAU

2017

DOI 10.4467/25439561KSR.17.016.7886

Agata Kilar

Ignatianum

Kraków

\title{
ХРИСТИАНСКИЙ ПОХОРОННЫЙ ОБРЯД В РОМАНАХ ФЁДОРА ДОСТОЕВСКОГО И ЛЬВА ТОЛСТОГО
}

\author{
CHRISTIAN FUNERAL RITE IN THE NOVELS \\ OF FYODOR DOSTOEVSKY AND LEO TOLSTOY
}

\section{Streszczenie}

Tematem referatu jest chrześcijański obrządek pogrzebowy omówiony na przykładzie dwóch powieści Lwa Tołstoja: Wojny i pokoju (śmierć starego hrabiego Biezuchowa) oraz Anny Kareniny (zgon Mikołaja Lewina), a także dzieła Fiodora Dostojewskiego Bracia Karamazow (śmierć starca Zosimy, pogrzeb Iljuszy).

Przytoczone przykłady pokazują główne cechy obrzędu pogrzebowego praktykowanego w tradycji prawosławnej. W artykule główny nacisk został położony na ukazanie chrześcijańskich aspektów związanych z przygotowaniem zmarłego do jego ostatniej drogi, a także na to, jak ważne jest przestrzeganie tych rytuałów w tradycji chrześcijańskiej, w szczególności rosyjskiej. Aby w pełni ukazać specyfikę pogrzebowego obrzędu, autorka omówiła różne rodzaje pochówku: laika, mnicha i dziecka. Dzięki temu czytelnik zobaczy, że XIX-wieczna literatura rosyjska zaczerpnęła sposób przedstawiania śmierci i obrzędu pogrzebowego bezpośrednio z chrześcijaństwa, jednocześnie korzystając ze specyfiki literackiego języka rosyjskiego i tradycji prawosławnej. Czytelnik dowie się, że przypadki śmierci i związanych z nimi rytuałów są zdefiniowane przez tradycję i prawosławne pojmowanie śmierci.

\section{Summary}

The theme of the essay is the Christian funeral rite is discussed based on two novels by Leo Tolstoy: War and peace (the death of old count Bezuchow) and Anna Karenina (the death of Nikolai Levin), as well as works F. Dostoevsky, The Brothers Karamazov (the death of the 
old man Zosima, funeral of Iliusza). The arguments are intended to show the features of the funeral rites in the Orthodox tradition.

In the presentation the main emphasis is to raise the visibility of Christian aspects related to the preparation of the deceased to his last path, but also pay attention to how important rituals in the Christian tradition, then the Russians. Account was taken of different types of burial: layman, monk and child, in order to fully show the specificity of the Orthodox funeral rite.

The examples are intended to demonstrate that nineteenth-century Russian literature adopted the image of death and the funeral rites annually on Christian soil the Russian language combined with the traditions of the Orthodox. Show that cases of death and related rituals are predefined this tradition and affiliated with the Orthodox understanding of death.

Słowa klucze: tradycja prawosławna, chrześcijaństwo, pogrzeb, rytuał, literatura rosyjska, śmierć

Key w ord s: the Orthodox tradition, the Christian funeral rite, ritual, Russian literature, death

Смерть - это одно из наиболее травматических переживаний в жизни каждого человека. Встреча с ней, по мнению Альфонса Ди Ноли, является дезинтегрирующим жизнь переживанием не только для всего общества, но также и для индивида ${ }^{1}$. Воспринимаемая. как один из базовых элементов человеческого существования, неоднократно как что-то негативное, несущее боль и пробуждающее страх.

С самого начала человечества смерть шокировала человека, но и восхищала. Практически всегда он задумывался, над тем, что его ждёт после окончания его земного существования. Эти мысли вели к возникновению бесчисленного количества произведений, в которых художник пытался ответить на поставленный вопрос - что меня ждёт после смерти?

Художники очень часто в своих произведениях используют мотив смерти, рассматривают его смысл и значение, чтобы хоть в небольшой степени понять этот феномен. По словам Майкла Кэрригана, независимо от страны, эпохи и культурного круга заинтересованность смертью и похоронным обрядом существует и будет существовать, независимо от актуальных убеждений, потому что:

„Dawne kultury często personifikowały śmierć - siłę, którą usiłowały zrozumieć od zarania dziejów - przedstawiając ją jako różnorodne, mściwe lub dobrotliwe bóstwa"².

Явлению смерти очень часто сопутствует определенный обряд. В зависимости от вероисповедания или культуры, в которой мы воспитаны, обряды эти будут отличаться, но цель они имеют одну - помочь усопшему на его пути

${ }^{1}$ A. M. di Nola, Triumf śmierci. Antropologia żałoby, red. nauk. M. Woźniak, tłum. J. Kornecka [et al.], Kraków 2006, s. 9-11.

${ }^{2}$ M. Kerrigan, Historia śmierci. Zwyczaje i rytualy pogrzebowe od starożytności do czasów wspótczesnych, thum. S. Klimkiewicz, Warszawa 2009, s. 9-21. 
к Богу. В христианской традиции при усопшем читаются определенные церковным правом молитвы, после этого, тело укладывается во гроб. Отец Марк Блаза в своей статье Modlitwa za zmarlych w Kościele prawosławnym пишет, что первые христиане молились за умерших через несколько дней после похорона, а также через год после смерти. А Сегодня в римско-католической церкви начало ноября-это время особой памяти о погибших. Католики молятся за спасение всех умерших ${ }^{3}$.

В православной церкви мы находим информацию на тему необходимости молитвы за умерших. Относительно православной теологии, после смерти душа человека отделяется от тела и «переносится» в безтелесный мир, где наступает ее самоопределение. Самоопределение часто называют судом детальным, вступительным или частичным, потому что он не имеет окончательного характера ${ }^{4}$. Это так называемое «хождение души по мытарствам», во время которого душа испытывается злыми духами, но одновременно стерегут её ангелы ${ }^{5}$. Тофилюк добавляет, что в момент, когда душа закончит свое хождение по мытарствам, предстает перед лицом бога, где проходит суд окончательный и может обрести спасение ${ }^{6}$.

В православной традиции, добавляет Тофилюк, очень важен сам момент погребения и действий, исполняемых близкими и священником при усопшем. Литургические правила говорят нам о 5-и вариантах похоронного обряда: детей, светских, священников, монахов и тех, кто умер во время октавы пасхи‥ Каждый из пяти вариантов погребения имеет свою индивидуальную форму, которая строго соблюдается священником.

В русской литературной традиции мотив смерти занимает очень важное место. Наравне с мотивом рождения он указывает нам полноту человеческой жизни. Двое ярчайших представителей этой литературы: Ф. Достоевский и Л. Толстой в своем творчестве неоднократно затрагивали тему смерти. Каждый из них представлял одно и то же явление, но иначе. Очень часто влияли на это личные переживания, а также концепция человека. Однако, необходимо заметить, что в любом случае указывали они на связь этого обряда с православной традицией и укоренившимся в ней образом смерти. Черпали они из традиционных источ-

${ }^{3}$ M. Blaza SJ, Modlitwa za zmartych w Kościele prawosławnym, „Przegląd Powszechny” 11/1011, listopad 2005.

${ }^{4}$ A. Sarwa, Rzeczy ostateczne czlowieka i świata. Eschatologia Kościoła wschodniego, Łódź 2002, s. 80-90.

${ }_{5}$ M. Blaza SJ, op. cit.

${ }^{6}$ J. Tofiluk, Eschatologia. Wyznanie prawosławne [w:] Porównanie wyznań rzymsko-katolickiego, prawosławnego, ewangelicko-augsburskiego, ewangelicko-reformowanego, pod red. A. Zuberbiera, E. Pokorskiej, Warszawa 1988, s. 124-125.

${ }^{7}$ Ibidem. 
ников, чтобы в полной мере показать, что смерть и обряд, которым является погребение, имеют глубокие корни в христианской религии. При описании обрядов старались они не относиться к языческой традиции, но элементы язычества проникали в их творчество. Примером служат похороны Ильюши - героя романа Ф. Достоевского Братья Карамазовы. Там знакомые напоминают отцу, чтобы он покрошил хлеб во гроб сына. Несомненно, оба писателя точно передали эмоции, сопровождающие прощанию умершего, а также представили обряд похорон согласно христианской традиции.

Фёдор Достоевский запечатлелся в русской литературе не только как гениальный, полный нравственной страсти писатель, но также как писатель сомневающийся. Его считают мастером психологической прозы, он интересовался проблемами обычных людей. Большинство исследователей Достоевского экспонирует значение христианской антропологии в образе человека в его произведениях. Среди них можем выделить: М. Бердяева, М. Бахтина, В. Соловьева, Ч. Милоша, А. Разьны и И. Тишнера ${ }^{8}$. В своих работах относительно этого писателя они обращали внимание на факт, что для Достоевского очень большое значение имеют христианские ценности и вера в Бога. Автор Преступления и наказания, показывая мир полный ужаса, замечает, что даже в деградирующем мире, могут существовать люди, которые будут давать пример того, что добро и милосердие являются убежищем от страданий. Примером может служить Соня Мармеладова, которая своей верой в Бога и Его милосердие, была в состоянии вернуть с ложного пути Раскольникова. Среди героев Достоевского существуют также те, кто, несмотря на окружающие их зло, верно шагают по пути справедливости и любви Божьей.

Одним из таких положительных персонажей является герой известного романа Братья Карамазовы, старец Зосима, похороны которого Достоевский описал очень живописно и не отходя от тогдашних реалий. Зосима - это старец, праведник и учитель Алёши Карамазова, который пребывает в монастыре. Он имел силу врачевания и ясновидения, пользовался уважением среди односельчан. Взирая на его правые поступки все надеялись, что после смерти, случится чудо и его тело не будет разлагаться. Но этого не произошло, что сразу же используют противники Зосимы, объявляя, что старец вовсе не был так добр, как все думали, а тело, которое быстро разлагается - есть доказательством того, что он вел преступную и полную греха жизнь.

После смерти старца начались приготовления к погребению. Как известно, монахов погребают иным обрядом, чем остальных верующих. В своей книге

${ }^{8}$ М. Бердяев, Мировоззрение Достоевского, М. Бахтин, Проблемы поэтики Достоевского, A. Raźny, Fiodor Dostojewski - filozofia człowieka a problemy poetyki, J. Tischner, Nieszczęsny dar wolności. 
Misteria śmierci Н. Василядис пишет, что похоронный обряд православной церкви помогает человеку понять смысл и цель жизни 9 .

Согласно этим обрядам, во время погребения с телом усопшего монаха проводятся следующие церемонии: «Тело священнослужителя облачается во все одежды, соответствующие его сану, чем знаменуется, что на Страшном суде он будет держать ответ не только по исполнению христианского долга, но и по исполнению пастырского служения. Одежды должны быть новые и по цвету не черные, а светлых оттенков. В правую руку умершего архиерея и священника влагается крест, а на груди полагается Евангелие (...).Тело усопшего диакона полагается во гроб в полном диаконском облачении со вложеннным в руку кадилом, лицо его не покрывается воздухом.(...) Тело покрывается священным покровом во свидетельство веры Церкви, что умерший находится под покровом Христовым. На гроб архиерея возлагается мантия, а покров - сверх мантии. В руки покойного влагают икону Спасителя или Распятие. Вокруг гроба ставят четыре подсвечника со свечами: один у головы, другой у ног и два по обеим сторонам гроба; в совокупности они изображают крест и символизируют переход усопшего в Царство истинного света ${ }^{10}$ 》.

Исполняющий обряд священник читает фрагмент Евангелия, а собравшиеся у тела усопшего, поют заупокойные песни ${ }^{11}$.

Похожее происходило в ситуации со старцем Зосимой. Достоевский, хорошо зная обряды, господствующие во время погребения умерших, будь то светских или священников, верно передал читателям способ обращения с телом мертвого монаха. Описал момент приготовления тела к погребению, чтение Евангелия, а также преобладающее настроение после смерти среди населения и между братьями монашеской общины. В романе Достоевского можем прочитать:

«Тело усопшего иеросхимонаха отца Зосимы приготовили к погребению по установленному чину. Умерших монахов и схимников, как известно, не омывают. (...) Все это и исполнил над усопшим сам отец Паисий. После отирания одел его в монашеское одеяние и обвили мантиею: (...). На голову надел ему куколь с осьмиконечным крестом. (...) В руку ему положили икону Спасителя. (...) Так как усопший по чину был иеросхимонах, то над ним следовало иеромонахом же и иеродиаконам читать не Псалтырь, а Евангелие ${ }^{12 » .}$

${ }_{9}$ N. Vasiliadis, Obrzadek pogrzebowy, thum. A. Bień, K. Korszak http://dormitorium.lublin.pl/94/ obrz\%C4\%85dek-prawos\%C5\%82awny.htm [электронный документ, чтение 17.11.2015].

${ }_{10} \mathrm{https} / / /$ azbyka.ru/pogrebenie, дост. 17.11.2015.

${ }^{11}$ N. Vasiliadis, op. cit., http://dormitorium.lublin.pl/94/obrz\%C4\%85dek-prawos\%C5\%82awny. $\mathrm{htm}$ [электронный документ, чтение 17.11.2015].

12 Ф. Достоевский, Братья Карамазовы, https://vk.com/doc182722547 388745311, с. 224 [электронный документ, чтение 27.02.2016]. 
Чтение Евангелия над усопшим продолжалось три дня, как гласил обычай. Также Достоевский не упустил этого в своей повести. Читаем в Братьях Карамазовых, что при усопшем всегда кто-то находился и читал священные книги. Все наставления связанные с погребением были четко исполнены. Ни от одного не отступили, потому что, благодаря им, душа направлялась к Богу. В соответствии с православной традицией старец Зосима был предан земле. Уход старца Зосимы не имел характера прощания с жизнью, а наоборот - был началом нового пути, в конце которого ждет человека милосердный Бог-Отец. Автор Братьев Kapaмaзовых с помощью нескольких слов и жестов смог передать читателям свою уверенность, что после смерти, благодаря обрядам, которые исполняют живые за душу усопшего, по другую сторону ждёт нас тот, который был, есть и будет всегда нашим началом и концом. Сопутствует этому определенный вид надежды имеющей метафизический характер. Это надежда на новую жизнь, которая развивается в мире, где есть любовь, добро и мир.

Именно для того, чтобы достичь цель вечной жизни и встречи с Создателем, необходим обряд сопутствующий прощанию с усопшим.

Православная традиция устанавливает особую церемонию погребения ребёнка. В этом случае также существуют определенные обряды. Отец М. Блаза пишет, что если ребёнок умрет в возрасте семи лет, то похороны должны быть короткими, а литургия убогой. Это связано с тем, что дети не приступили еще к таинству святой исповеди и не могли в полной мере отличить добро от зла, приняли, однако, таинство святого крещения и были очищены от первородного греха. Во время похорон участвующие сосредотачиваются на невинности покойного ребёнка, а не на просьбах, мольбах о спасении его души ${ }^{13}$.

Фёдор Достоевский в Братьях Карамазовых описал похороны ребёнка. Это были похороны Ильюшечки, сына капитана Снегирева. Мальчик серьёзно болел и в последствии умер. Роман Достоевского заканчивается сценой погребения ребёнка. Фёдор Михайлович в следующих словах описывает этот момент:

«В голубом, убранном белым рюшем гробе лежал, сложив ручки и закрыв глазки, Илюша. Черты исхудалого лица его совсем почти не изменились, и, странно, от трупа почти не было запаху. Выражение лица было серьезное и как бы задумчивое. (...). В руки ему вложили цветов, да и весь гроб был уже убран снаружи и снутри цветами, (...). Ниночка в последний раз прильнула губами к устам покойного брата, когда проносили гроб мимо нее ${ }^{14} \gg$.

Момент прощания с усопшим, который описывает в романе Достоевский, практиковался в православной традиции с древних времен. А Василядис вспо-

${ }_{13}^{13}$ M. Blaza, op. cit.

${ }^{14}$ Ф. Достоевский, op. cit., https://vk.com/doc182722547 388745311, с. 517, дост. 27.02.2016. 
минает о последнем поцелуе, который живые должны отдать усопшему в благодарность Творцу/Создателю ${ }^{15}$. Это несет надежду на то, что возродится он в Господе и начнёт вечную жизнь. Эта надежда помогает близким пережить самый трудный период - траур в связи со смертью ребёнка. Описывая этот момент Достоевский выразил всю боль семьи погибшего ребенка, показал всю экспрессию чувств не только в поведении сестры Ильюшки, но и его матери и отца. Поцелуй живых, возлогающися на губах усопшего, является актом выражающим человеческую любовь вытекающую из глубокой душевной потребности ${ }^{16}$. Такой жест подчеркивает факт, что умерший является достойным уважения. Можно заметить, что Достоевский осознанно применил этот прием, чтобы подчеркнуть невинность мертвого ребёнка.

В следующей части мы узнаем, как выглядели похороны мальчика в церкви: «Прибыли наконец в церковь и поставили посреди её гроб. (...) Наконец приступили к отпеванию, роздали свечи. (...) После обычного обряда могильщики гроб опустили» ${ }^{17}$. Достоевский в мельчайших подробностях представил всю церемонию. Описал эмоции, скорбящих, а также представил сам момент опускания гроба в могилу. Можем прочитать у Василядиса, что образование процессии является естественным элементом во время выноса тела из дома в церковь и на кладбище. Все шествие удерживается в тесном порядке. В первых рядах несется Крест, как символ победы Христа над смертью, затем - свечи, а после - хор и священники с лампадами. За ними несут гроб с покойником, а за ним идёт семья и остальные участники церемонии ${ }^{18}$. В романе великого русского писателя весь порядок погребальной церемонии соблюден. Верный христианской традиции, он не пропустил существенных элементов в такой важной церемонии для каждого человека. В словах романа, описывающих сложение мальчика в могилу видна вера в то, что по ту сторону ждёт его лучшая и более красивая жизнь, потому что он сможет соединиться со своим Отцом.

Автор, описывая обряд, связанный с переходом души в другой мир, показывает свою веру в милосердие Бога, загробную жизнь а также спасение души, которое характерно для всех христианских конфессий. У православных обряд погребения тесно связан с христианской традицией, которая является его источником. Достоевский неоднократно прибегает к христианским традициям практиковавшимся ещё у начала христианства. Автор показывает типичный православный подход к вопросам смерти. Не упоминает он об осуждении и аду. Его герои перед лицом смерти соглашаются с Создателем и покорно отправляются

${ }^{15}$ N. Vasiliadis, op. cit., http://dormitorium.lublin.pl/94/obrz $\%$ C4\%85dek-prawos $\%$ C5\%82awny. htm, дост. 17.11.2015.

${ }^{16}$ Ibidem.

${ }_{17}$ Ф. Достоевский, Братья Карамазовы....,

${ }_{18}$ N. Vasiliadis, op. cit., 
на встречу с Ним, искренне веря в то, что после смерти Он позволит им увидеть Свое лицо.

Другим российским писателем, который в своем творчестве неоднократно поднимал тему смерти, был Лев Николаевич Толстой.

Лев Толстой, четвёртый из пяти детей, уже в детстве узнал, что такое смерть. Трагический опыт в детстве, сначала смерть матери, а через несколько лет спустя - отца, оставили во взрослой жизни Льва и его творчестве свой след. Автор произведений: Анна Каренина или Война и мир проявил себя, прежде всего, как психолог, знаток человеческого характера. Как пишет А. Семчук, Толстой изза тяжелого жизненного опыта и мировоззрения вошел в конфликт с церковью и был от нее отлучен. Несмотря на смену мировоззрения его взгляды на смерть не изменились. Как до, так и после мировоззренческого кризиса, Толстой одиноково решал вопросы веры ${ }^{19}$.

Как выдающийся знаток человеческого характера, Лев Николаевич описывал разные проблемы человека и методы борьбы с ними. Неоднократно на страницах своих романов говорил на тему смерти, погребального обряда, имеющего свой источник в российской христианской традиции. Исследователи его творчества: В. Шкловский, А. Семчук, Б. Эйхенбаум, М. Здеховский, часто обращали внимание на значение христианской традиции в его творчестве а также влияния, которое оказала на духовность Толстого смерть матери, а потом отца. Одно из произведений, в которых Толстой представил погребальный ритуал это Война и мир.

В романе Толстой описал несколько похорон. Однако, предметом обсуждения будет описание похорон князя Безухова. Случай смерти старого аристократа - является первым описанным в романе летальным исходом.

Последние минуты жизни графа автор Войны и мира описал в следующих словах: «Он лежал прямо под образами; обе толстые, большие руки его были выпростаны из-под одеяла и лежали на нем. В правую руку, лежавшую ладонью книзу, между большим и указательным пальцами вставлена была восковая свеча, которую, нагибаясь из-за кресла, придерживал в ней старый слуга. Над креслом стояли духовные лица в своих величественных блестящих одеждах, с выпростанными на них длинными волосами, с зажженными свечами в руках, и медленно-торжественно служили. (...); как бы в церкви, мужчины и женщины разделились. Все молчало, крестилось, только слышны были церковное чтение, сдержанное, густое басовое пение и в минуты молчания перестановка ног и вздохи. (...). В средине службы голоса духовенства вдруг замолкли; духовные лица шопотом сказали что-то друг другу; (...). Звуки церковного пения прекра-

19 A. Semczuk, Lew Totstoj, Warszawa 1987, s. 367-368. 
тились, и послышался голос духовного лица, которое почтительно поздравляло больного с принятием таинства ${ }^{20} \gg$.

Погребальный обряд был проведен согласно старым православным ритуалам, проводимым церковью. Безухов перед смертью принял все необходимые таинства, которые предусматривает русская христианская традиция. Это так называемое соборование ${ }^{21}$. Толстой представил смерть старого графа без лишнего шика. Описал то, что является главным - принятие таинства, пение, молитвы у тела усопшего - действовавший на протяжении веков погребальный ритуал, освященный христианской традицией.

Автор Bойны и мира показал в романе как умирает человек, смирившийся с судьбой. Используя терминологию Филиппа Ариэса, смерть Безухова мы можем зачислить к категории, названной французским исследователем - освоенной смертью 22 . Старый граф был похоронен согласно традиции и вере, что его ждет загробная жизнь и встреча с Господом на Страшном Суде.

Следующий пример, говорящий о том, что русский погребальный обряд исходит из христианской традиции - это смерть Николая Дмитрича Левина, героя романа Анна Каренина, брата Константина Левина. Он больной, мы видим изможденную фигуру, интеллектуала, который в присутствии Константина и его жены умирает от туберкулеза.

Схоже со случаем Безухова, Николай Левин принял таинства необходимые для достойной встречи с Богом. Исповедался и принял святое причастие. Благодаря этому он мог спокойно ожидать смерти. Однако прежде, чем она наступила, старший из Левиных очень страдал и требовал присутствия брата. В момент его смерти присутствовал священник, который читал молитву за умирающих. Как мы можем догадываться, была это молитва за умираюшего в муках. Как пишет о. Марк Лаврешук: „Zgodnie z Wielkim Typikonem zalecane jest odsłużenie Obrzędu

20 Л. Толстой, Война и мир, http://vk.com/doc17604442_162770688?hash=ac9c5db97953a c2a65\&dl=28aabb49a7217e1962, т. 1, с. 86-88, дост. 29.02.2016. Этот обычай согласен российским похоронным обрядам. V. Belyaeva, Śmierć w tradycji rosyjskiej - obrzędy cerkiewne, ludowe i socjalistyczne, http://etnologia.pl/europa/teksty/smierc-w-tradycji-rosyjskiej.php, дост. 23.11.2015.

${ }^{21}$ Соборование - это Таинство, в котором при помазании тела елеем на больного призывается благодать Божия, которая исцеляет немощи духовные и телесные. Таинство называется соборованием, потому что его в идеале должен совершать «собор» из семи священников. История Таинства восходит к апостолам, которые, получив от Иисуса Христа власть «исцелять болезни», «многих больных мазали маслом и исцеляли» (Мк. 6:13). Во время совершения таинства читают семь текстов из Апостольских посланий и семь - из Евангелия. После каждого чтения священник совершает помазание чела, щек, груди и рук тяжелобольного освященным маслом - елеем. По окончании последнего чтения Священного Писания он возлагает раскрытое Евангелие на голову соборуемого и молится о прощении ему грехов. http://azbyka.ru/1/eleosvyaschenie, дост. 29.02.2016.

${ }_{22}$ К этой категории Арес относит смерть в собственной постели, уникальную смерть духа, а также всех, кто к ней подготовлен и ожидает ее без тени страха. F. Ariès, Czlowiek i śmierć, thum. E. Bąkowska, Warszawa 2011, s. 19-42. 
na rozłaczenie duszy i ciała, kiedy człowiek dtugo cierpi. Modlitwa ta, składa się z kanonu i dwóch modlitw. Pierwsza modlitwa: Modlitwa o sądzonej duszy jest w pełni tożsama z modlitwą czytaną w trakcie Kanonu modlitewnego ... przy rozłączeniu duszy i ciała. O treści drugiej modlitwy wiele mówi jej nazwa: $O$ śmierci człowieka dtugo cierpiącego. W modlitwie wznosimy prośby o uwolnienie sługi bożego od bólu i cierpień związanych z chorobą i o przyjęcie jego duszy" ${ }^{23}$. Можем заметить, что во время смерти Николая Левина были сохранены все ритуалы, необходимые для того, чтобы после смерти его душа была спасена.

Этот пример позволяет твердить, что традиционные христианские ценности, а также элементы погребального обряда в эпоху Льва Толстого, признавались даже скептиками, к которым относился Николай Левин. Мало верующий или не верующий в Бога в момент приближения смерти снова обращается к Творцу и ожидает Его прощения. На смертном одре они отдают себе отчет, что только Бог может их спасти и обеспечить им вечную жизнь.

Погребальные обряды, представленные Толстым в его романах, имеют глубокие корни в православной традиции. Его личные переживания привели к тому, что Толстой выражал определенный скептицизм относительно веры в Бога, и это просматривается в его творчестве. Однако это не меняет факта, что в присутствии смерти его герои выражали полное осознание христианских ценностей и были готовы к встрече с Богом. Несмотря на его взгляды на религиозные темы дух христианской традиции постоянно присущ на страницах его романов. Даже столь радикальный писатель, как Толстой, не смог окончательно порвать с глубоко укорененной традицией.

Представленные в этой статье образы смерти и связанные с ними погребальные обряды позволяют утверждать, что у обоих писателей, как Достоевского, так и Толстого представление смерти определяется православной традицией, а также православным пониманием смерти ${ }^{24}$. Вера в жизнь после смерти, встреча с Господом, Страшный Суд и награда или наказание после смерти, все эти элементы характерные для каждой христианской конфессии. Православная религия в этом случае не отличается.

${ }^{23}$ M. Ławreszuk, o., Obrzędy pogrzebowe w Kościele prawosławnym, http://sakramenty.cerkiew. pl/pogrzeb-czytelnia, http://sakramenty.cerkiew.pl/pogrzeb-czytelnia, дост. 23.11.2015).

${ }^{24}$ В православной традиции жизнь-это момент преходящий, определенный этап на пути к вечной жизни; это период испытания. В течение земной жизни человек работает, а его поведение является показателем будущей жизни. Творец определяет время ухода человека из этого мира, а ближний должен радоваться, что кто-то из его семьи присоединился к ангельскому хору. Смерть должна быть поводом для тихой радости от того, что Бог, в конце концов, взял своего любимого ребенка к себе, а траур должен быть посвящен молитве и размышлению над жизнью. По учению православной церкви, смерть-это рубеж, который представляет собой конец действий и поступков верующего на земле, и в то же время начинается время получения награды или наказания. И. Панкеев, Обычаи и традиции русского народа, Москва 1999, с. 516-517. 
В православной христианской традиции, как сообщает Вероника Беляева, вечная жизнь человека начинается уже в момент зачатия и делится на три этапа ${ }^{25}$. Смерть является последним из них, который ведет к Богу. Благодаря таинствам, которые в христианской традиции Россиян появились с приходом христианства на их земли, живущие помогают умирающим в их последнем пути. Приведенные здесь примеры свидетельстую об этом.

Фёдор Достоевский и Лев Толстой, несмотря на идейные и мировоззренческие различия одинаково отображают погребальные обряды своих героев. В 20-м веке, когда прозвучали последние отголоски большевитской революции, в официальном русле русской литературы мы не найдем больше таких изображений смерти и похорон. Именно Достоевский и Толстой закрепили этот образ, а продолжали писатели эмигранты: Иван Бунин, Борис Зайцев или Иван Шмелев. Советская литература в своей основе удаляла религиозные элементы не только из описаний жизни человека, но также из повествований о смерти.

\section{Bibliografia}

Ariès, F., Człowiek i śmierć, thum. E. Bąkowska, Warszawa 2011, Belyaewa, V., Śmierć w tradycji rosyjskiej - obrzędy cerkiewne, ludowe i socjalistyczne, http://etnologia.pl/europa/ teksty/smierc-w-tradycji-rosyjskiej.php.

Blaza, M., Modlitwa za zmarlych w Kościele prawostawnym, „Przegląd Powszechny” 11/1011, listopad 2005.

Достоевский, Ф., Братья Карамазовы, https://vk.com/doc182722547 388745311.

Kerrigan, M., Historia śmierci. Zwyczaje i rytuaty pogrzebowe od starożytności do czasów współczesnych, tłum. S. Klimkiewicz, Warszawa 2009.

Ławreszuk, M., o., Obrzędy pogrzebowe w Kościele prawosławnym, http://sakramenty.cerkiew.pl/pogrzeb-czytelnia.

Nola, A. M. di, Tryumf śmierci. Antropologia żałoby, red. nauk. M. Woźniak, thum. J. Kornecka [et al.], Kraków 2006.

Панкеев, И., Обычьии и традиции русского народа, Москва 1999.

Sarwa, A., Rzeczy ostateczne czlowieka i świata. Eschatologia Kościoła wschodniego, Łódź 2002.

Semczuk, A., Lew Totstoj, Warszawa 1987.

Tofiluk, J., Eschatologia. Wyznanie prawosławne [w:] Porównanie wyznań rzymsko-katolickiego, prawostawnego, ewangelicko-augsburskiego, ewangelicko-reformowanego, pod red. A. Zuberbiera, E. Pokorskiej, Warszawa 1988.

25 Беременность представляет собой первый этап вечной жизни, второй - это жизнь на земле, а смерть начинает третий этап. V. Belyaewa, Śmierć w tradycji rosyjskiej-obrzędy cerkiewne, ludowe i socjalistyczne, http://etnologia.pl/europa/teksty/smierc-w-tradycji-rosyjskiej.php, дост. 24.11.2015. 
Толстой, Л., Война и мир, http://vk.com/doc17604442_ 162770688?hash=ac9c5db97953ac2 a65\&dl=28aabb49a7217e1962, т. 1.

Vasiliadis, N., Obrzadek pogrzebowy, thum. A. Bień, K. Korszak http://dormitorium.lublin. pl/94/obrz \%C4\%85dek-prawos\%C5\%82awny.htm.

Сайт http://azbyka.ru/1/eleosvyaschenie, дост. 29.02.2016.

Сайт https://azbyka.ru/pogrebenie, дост. 17.11.2015. 